15 Grifton, Henri. Design et Utopie Dijon, Hazan, 2000

16 Copella Juli. "Normalitá della differenza-standardizzazione vera de unicitá, oggetti uguali-oggetti differenti" en Domus, № 781,1996 differenza standardizzazione del unicitá, oggetti uguali-oggetti different in Domus, № 781,1996 .

\section{La dimensión}

Los diseños aparecen como una posibilidad, porque en una medida de lo mínimo pueden realizarse en plenitud, como obra completa. En el montaje de una exposición cuya ley es la levedad, utilizando escasos recursos, permite encontrarse con una experiencia tangible. La limitante juega en este caso a favor de la posibilidad, en la voluntad de construir aprovechándose de las virtudes de esos recursos con que se disponía y no otros.

En relación a esta medida de lo mínimo como aquella que abre posibilidad, es que se presenta la dimensión del auto-encargo. Pocos elementos participan, pudiendo quedar fuera aquellos que involucran decisiones externas que cambian el destino de una idea a ejecutar. La cercanía de encontrarse con una idea propia cobrando realidad se hace realidad en esta ley de lo mínimo.

\section{Lo diverso}

¿Hacia dónde dirigir la flecha de Herakles?

En los diseños, los campos de acción son tan amplios y diversos como un mar que se escurre por los oficios del mundo.

La actualidad nos cobra una actitud decidida. Hay muchas direcciones hacia donde apuntar, y varias flechas pueden viajar en simultáneo. De

degree that can be fully realized, as complete works. Assembling an exhibition governed by lightness, using few resources, becomes a tangible experience. The limiting feature in this case favors the possible, the will to build, using the strengths of the resources to hand and nothing more.

Associated with this minimum degree that opens possibilities, the dimension of personal commitment arises. Few elements are involved, and we can leave out those that need external decisions, which change the direction of the ideaproject. In this law of the minimum we realize the dream of realizing our own idea.

\section{Diversity}

Where to aim Hercules' arrow? In design the fields of action are as broad and diverse as a sea that runs through all the crafts of the world These are times that demand we be decisive. There are many directions to aim toward and several arrows can fly simultaneously. They may create connections within diversity.

I offer my own activities as an example: I am installing an exhibition in lightness, building furniture with solidity, and studying for a course on animal structures in science. From the point ellas puede surgir una conexión entre lo diverso. Pongo como ejemplo mis actuales ocupaciones: un montaje expositivo en la levedad, construyendo muebles en la consistencia, estudiado para un curso de estructuras animales en la ciencia. Desde el diseño, cada una de estas actividades posee una materia con la que trabaja, y en mí, la voluntad de construir entre ellas una relación que las conecte, como vasos comunicantes que me ayudan a entender de manera más completa y bajo diversos ángulos, los problemas que proponen: como el del tiempo; el tiempo de lo leve del montaje que se juega en lo inmediato, frente al tiempo de la madera bruta para convertirse en mueble, frente al tiempo del estudio para llegar a algo.

Ese simultáneo de lo diverso, fortuito o dirigido, lleva consigo un camino que uno construye buscando el reincidir sobre nuestra materia de trabajo, ese lugar donde se reúne lo diverso, ese que se nos hace habitual y que nos lleva por el camino de la maestría.

\section{Miguel Eyquem Via}

1, Universidad Católica de Valparaíso, 1992. En 1993 inicia su actividad docente en las universidades Católica y del Bío-Bío, desempeñándose actualmente como profesor a cargo de Extensión de la Facultad de Arquitectura y Diseño de la Universidad Andrés Bello. Entre sus trabajos destacan el diseño de mobiliario urbano y de interior.

of view of design, each activity has a subject matter with which I work, and I have the will to relate them, connect them, help them find their level, like water, to help myself understand more completely and from different angles the problems they pose. Among them, the problem of time, for example; the time of the light installation that is immediate, compared with the time it takes rough-cut wood to become a piece of furniture, or the time it takes to study and achieve something.

The simultaneous quality of diversity, by chance or by design, leads to the path we make as we attempt to recreate our raw materials, the spot where diversity meets, that becomes familiar and leads us along the path to mastery.

Miguel Eyquem Vial Industrial designer, Catholic University of Valparaíso, 1992. In 1993 he began teaching at the Catholic University and the University of the Bio-Bio, and now directs the extra-curricular department of the Faculty of Architecture and Design at the University of Andrés Bello. His work includes the design of urban and interior installations.

\section{¿Con qué objeto? Gonzalo Puga Larraín}

"Entre las nuevas generaciones son menos numerosos los que asignan al futuro una alternativa utópica. Muchos parecen baber becho propio el famoso slogan de mayo del '68 'aquí y abora': ser capaz de intervenir sobre la realidad se transformó en el mayor reto, el colmo de la utopía" ${ }^{15}$. -Henri Grifton-

En un debate público de Henry Van de Velde en 1914 en la Deutsche Werkbund, Hermann Muthesius sostuvo que sólo la estandarización hace posible el desarrollo de un gusto seguro y universalmente válido ${ }^{16}$. Con el protagonismo de la producción industrial en serie como paisaje de fondo, el diseño empieza poco a poco a traducir formas tradicionales en el novedoso sistema productivo. Después se preocupará de otorgarle legitimidad y señalar las limitaciones de las maquinarias y de los procesos que realizan. Surge un orden nuevo.

El trabajo de Peter Behrens para AEG ya constituía un modelo. A diestra y siniestra las geometrías de revolución y extrusión, los ángulos rectos y planos se van multiplicando a un ritmo comparable con la proliferación actual de los

\section{What For? \\ Gonzalo Puga Larraín}

"Fewer of the new generations see a Utopian alternative for the future. Many of them seem to bave adopted the slogan of May '68 - "bere and now"- and being able to intervene reality has become the greatest challenge, the ultimate Utopia." 15 -Henri Griffon-

In a public debate with Henry Van de Velde in 1914 in Deutsche Werkbund, Hermann Muthesius held that only standardization would allow the development of a secure and universally valid taste. ${ }^{16}$

Against a backdrop of industrial mass production, design begins, little by little, to translate traditional forms into the new productive system. Later it will take on the task of legitimizing the system and showing up the limitations of the machines and their processes. A new order is emerging.

The work of Peter Behrens at AEG was already a model. The geometry of revolution and extrusion, right angles and planes, multiply right and left, at a speed we would compare today with the proliferation of hyper-links and hypertexts in computing. Attention centers on the logic of 
17 "The 5k awards" en www.the5k.org/ 18 Su difusión reciente en occidente se produce a partir del libro de Camilla Art 1863-1922 publicado en Londres N Nueva York en 1962, y de las exposiciones londinenses The Non(a) y Tatlin's Dream en la galería Fisher Fine Art en noviembre del mismo año (9 Castelli. Clino Trini. Transitivo Design 19 Castelli, Clino Trini
20 Buur, Jacob. "Japanese methods of Design $D K, n^{\circ} 2,1991$ 21 En su libro Future Perfect, Stanley customization como termino mass de la producción masiva y aquella a medida del consumidor. 22 Marzano, Stefano. Creating Value by Design, Blaricum, $\mathrm{V}+\mathrm{K}$ Publishing,
ARQ hipervínculos o hipertextos en la computación. La atención se concentra en la lógica productiva lineal y los consumidores están dispuestos a adaptarse, a adquirir productos de consumo con fe en la tecnología y la industria, sinónimos de motores del desarrollo y del mejoramiento de la calidad de vida. Con deseos parecidos a los de Stewart Butterfield, precursor del concurso de diseño para páginas de Internet con menos de 5 kilobytes de datos ${ }^{17}$, en el primer tercio del siglo XX El Lissitsky, Casimir Malevitch, Alexander Rodchenko y Varvara Stephanova, investigaban la economía en la forma y la eficiencia del material. Sin embargo, estas posturas austeras acabarán convirtiéndose en motivo de culto elitista. Sólo cuando la industria logre generar formas complejas, gracias a medios digitales, el Constructivismo será un fetiche para el consumo del público masivo en los ochenta ${ }^{18}$.

Controlar los sistemas productivos y gestionar su creciente complejidad, junto a las posibilidades mímicas de los materiales plásticos que propician la creación de lenguajes que hacen de la industria evolucionada un punto clave, determinante del potencial de diseño de los países donde se ubica. Un ejemplo: Norman Bel Geddes impulsó el potencial simbólico del Streamline, que cruza optimista la vastedad del territorio estadounidense y de su imaginario colectivo, evadiendo la crisis industrial de la época. A partir de la World's Fair de Nueva York (1939), los términos seguridad, confort, velocidad y economía no serán incompatibles ${ }^{19}$. $\mathrm{O}$, en la vertiente europea, la sensualidad de los productos Olivetti, diseñados por Marcello Nizzoli, igual que las máquinas de coser Necchi, ayudan a conquistar la reputación internacional de la que gozan las marcas del diseño italiano.

Las expresiones plásticas del diseño, por otra parte, adquieren un papel primordial en la aceleración de la obsolescencia de los productos; incluso llegará a programarse. Contrario a esta práctica, Eliot Noyes, quien estudió arquitectura en Harvard (donde conoce a Walter Gropius y Marcel Breuer), gracias a estar a cargo del departamento de diseño de la IBM y optar ahí por el reduccionismo como estrategia, con la atención puesta en las normas de integridad de la marca y en la eficacia de los productos, sigue en Estados Unidos la tradición de la Bauhaus.

$\mathrm{Al}$ alero de esta empresa y de otras parecidas, los departamentos de diseño han estado asociados a los de investigación y desarrollo, y logran dar una forma atractiva a los productos que resultan de las tecnologías nuevas. Los equipos de trabajo de estas compañías incluyen, entre otros, especialistas en gestión de proyectos, análisis de mercado, imagen corporativa, factores humanos y formas de uso, ingenieros mecánicos, diseñadores de interfases, expertos en color y modelistas, y reconocen la importancia de buscar un flujo de trabajo continuo y sin interrupciones, que optimiza el trabajo y acelera la llegada de los proyectos al mercado. En este panorama los diseñadores desarrollan herramientas de análisis y persuasión específicas para su profesión. Metodologías de trabajo, con base en métodos estadísticos y matemáticos de clasificación y evaluación de resultados, facilitan el diálogo con otros profesionales, lo que otorga a las grandes compañías un potencial de gestión de la innovación prohibitivo para competidores menores.

En Japón, país cuyo ciclo de desarrollo de productos ha sido más rápido que el europeo y donde el nivel innovativo de cada producto es menor, las herramientas de análisis y desarrollo respondieron a la realidad de las compañías, y también a una estructura social jerárquica en la que la visión individual del proyectista tiene menos relevancia. Así, se desarrollan sistemas de cuantificación de los anhelos del consumidor, aplicables por ejemplo a la determinación de la forma, posición y tamaño de las ventanas de un casete, como los diseñados para TDK en los años ochenta ${ }^{20}$. linear production and consumers are prepared to adapt, to buy consumer goods trusting in technology and industry, which are synonymous with development and a better quality of life.

In our days, Stewart Butterfield pioneered the design competition for Internet pages with fewer than five kilobytes of data ${ }^{17}$; the same motivation drove Lissitsky, Casimir Malevitch, Alexander Rodchenko and Varvara Staphanova in the first third of the $20^{\text {th }}$ century to investigate economy in the form and efficiency of materials. But their search for austerity led only to an elitist cult. It was not until industry could create complex forms, thanks to digitalization, that constructivism became a fetish of mass consumption, in the '80s. ${ }^{18}$

Once productive systems are under control and their growing complexity manageable, the conditions are ripe to use the systems and the plasticity of their materials with their scope for imitation, to create languages. Developed industry becomes the key point that determines design potential in the countries where it exists. To give one example: Norman Bel Geddes gave impetus to the symbolic potential of the Streamline, a shining optimism that crossed the vast territory of the United States and its collective imagination, shaking off the industrial crisis of the time. After the 1939 World Fair in New York, the terms safety, comfort, speed, and economy would never again be incompatible. ${ }^{19}$

And Europe's tradition brought the sensuality of Olivetti's products, designed by Marcello Nizzoli, or the sewing machines from Necchi, that helped Italian design brands win their international reputation.

The plastic expression of design, on the other hand, leads the way in speeding up product obsolescence; it is even programmed in. An opponent of this practice, Eliot Noyes, follows the tradition of the Bauhaus in the United States. An architecture student at Harvard, where he met Walter Gropius and Marcel Breuer, he headed the design department at IBM where he opted for reductionism as a strategy, and focused on regulating brand integrity and on product efficiency.

IBM and other companies have fostered the idea that design departments should be tied in with research and development, to give attractive form to products generated by new technologies. Work teams in such companies include specialists in project management, market analysis, corporate image, human resources and organization, mechanical engineers, interface designers, color experts and modelers. They recognize the importance of a continuous steady workflow, which gives the best results and speeds up the process of getting projects to market. In this framework, designers develop the tools of analysis and persuasion of their profession. Work methods based on statistical and mathematical models of classifying and evaluating results help the dialogue with other professionals, and give the major corporations a potential for innovation management that is beyond the reach of smaller competitors.

In Japan, where the product development cycle has been faster than in Europe, and innovation levels for each product less, the analytical and development tools relate to the corporate situation, and to a hierarchical social structure in which the individual vision of the designer is less important. Thus they have developed systems to quantify consumer demands, and apply them to, for example, the shape, position and size of the windows on a cassette, like those designed by TDK in the ' 80 s. $^{20}$

Adopting a strategy that ignores the statistical invention of the "average consumer", Nick Hayeck introduced the variable series ${ }^{21}$ in Swatch 
17 The 5k Awards" at www.the $5 k . o r g /$ 18 The recent diffusion of their ideas in the West begins in 1962 with the Camilla Gray's The Great Experime Russian Art 1863-1922, and with two London exhibitions, The Non-objectue Worla 1914-1955 in the Annely Juda Tatlin's Dream in the Fisher Fine At Gallery in November of the same year. 9 Castelli, ClinoTrini. Transitive Design. 19 Castelli,Clino Trini
20 Buur, Jacob. "Japa esign" in Design DK, № 2, 199 21 In his book Future Perfect, Stanley Davis suggests the term mas customization as the combination mass production and consumer

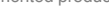
22 Marzano, Stefano. Creating Value by Design, Blaricum, V+K Publishing, 23 Colin, Christine (interview with Design et utopies, Dijon, Hazan, 2000. 24 "Good Goods" (catalogue), L redoute, 1998.

25 Mari, Enzo. "Autoconstrucción" (Self-construction) in Ottagono, № 122 1997
Con una estrategia que descuida al consumidor medio, producto de la estadística, al introducir la serie variada ${ }^{21}$, Nick Hayeck ha hecho protagonista del reloj Swatch al trabajo de diseñadores independientes, con encargos muy específicos, que le dan una imagen cambiante, superficialmente adaptable, que aprovecha la flexibilidad en los aspectos estilísticos, relevantes en su aceptación particular, sin intervenir en la innovación técnica del sustrato, producto de costosas inversiones. En el último tiempo la atención por la forma y la calidad ha resultado insuficiente, pues introducir en el mercado productos homólogos no representa grandes desafíos, y objetos fabricados en Japón, China o Suiza pueden ser técnicamente iguales. Al cambiar sólo su valor simbólico, la importancia de la comunicación cobra especial relevancia. Comunicación del producto, pero también del proyecto de futuro con el que la industria que lo produce se identifica. Como en casos conocidos, esta situación propicia la apertura al público de los centros de diseño de grandes compañías.

En particular, Philips Design, bajo la dirección de Stefano Marzano, abordó el proyecto de diseño como un sistema en el que la vida del consumidor es el objeto explícito de transformación. Busca identificar valores universales para desarrollar productos electrónicos.
"Un paraíso reconquistado" que modela la imagen de la compañía, y permite conocer y alimentar el imaginario de sus proyectistas y compradores ${ }^{22}$. Con diferentes matices, Tim TOM, el equipo de Thomson Multimedia que fuera dirigido en su origen por Philippe Starck, se ha basado en el estudio de "nuevas prácticas sociales, de innovaciones tecnológicas y en la intuición del diseñador", para realizar propuestas, como la chaqueta Krazy, que contaminan con lenguajes callejeros el mundo etéreo de estas grandes empresas ${ }^{23}$.

En otro terreno, el trabajo de diseño cambia de dimensión, para transformarse en un intangible, del tipo del de Philippe Starck para el catálogo de La Redoute. Su mano consistió en establecer filtros para elegir 200 productos "honestos y adecuados" para la selección de Good Goods, intentando moralizar el consumo en el fin del milenio, al retomar la utopía moderna de la multiplicación industrial del bien ${ }^{24}$.

Estos ejemplos, signos mutantes de la actividad de diseño, evidencian la avidez por la adaptación que hasta ahora ha permitido la subsistencia de este oficio múltiple, pero, a su vez, plantean el desafío de interpretar los proyectos de modo ajeno a aquel del consumo, para definir un cuerpo de conocimientos propio y necesario a esta disciplina, una disciplina que deambula entre la cualificación funcional, sensual, lingüística y moral de todos los productos que nos rodean.

"No amo los paisajes domésticos fingidamente articulados e inmutables, cualquiera sea la matriz de su vanguardia o banalidad. Su forma, asi arrogantemente definida de una vez por todas, corresponde -no paradojalmente- a aquella de una tumba. Prefiero estar involucrado en la realización de alguno de los ladrillos con los cuales cualquier persona pueda poco a poco, libremente, modificar su propio ambiente doméstico coberentemente a la propia evolución, como, por ejemplo, abrir una escuela de tango, adoptar siete hijos, dar inicio a una actividad de restauración de computadores arqueológicos" 25 . -Enzo Mari-

Gonzalo Puga Larraín

Diseñador, PUC de Chile, 1993. Magister en Diseño Industrial Domus Academy, Milán. Ha trabajado para Samsung, Seúl; Frogdesign, California, y como investigador y docente en Domus Academy. Actualment Arquitectura, Diseño y Estudios Urbanos de la PUC. watches and made independent designers its protagonists. They receive precise commissions that give the product a changing and superficially adaptable image, and makes use of flexibility in style to give it focused attraction, without introducing high-investment technological innovations.

Recently, attention to form and quality has ceased to be enough. It is easy to bring copycat products to market, and objects can be made, technically, to the same standard in Japan, China or Switzerland. But when only the symbolic value changes, communication becomes especially important The product must carry a message, but there also has to be a message from manufacturers about their image of the future. This development favors opening the corporate design centers to the public, and it is happening.

Philips Design, in particular, under its director Stefano Marzano practices design as a system in which the consumer's life is transformed, explicitly. Marzano seeks to identify universal values in order to develop electronic products. His "Paradise regained" models the company's image, and lets it learn about and nourish the imaginations of its designers and its customers. ${ }^{27}$ With a different emphasis the Tim TOM team at Thomson Multimedia, headed originally by Philippe Starck, has based itself on the study of "new social customs, technological innovation and the designer's intuition" to realize projects like the Krazy jacket, where street language invades the rarefied world of the great corporations. ${ }^{23}$

In a different field, design changes dimension and becomes intangible, for example in Philippe Starck's work for the La Redoute catalogue. His presence is there in the filter through which 200 "honest and adequate" products were chosen for Good Goods. The idea was to try to moralize consumption at the end of the millennium, by reclaiming the modern Utopia of industrially multiplying the good. ${ }^{2}$

These examples are the changing signs of design as activity. They bear witness to the adaptability that has allowed this multiple craft to survive. But they also offer the challenge of interpreting projects independently of consumption, of defining the body of knowledge proper and necessary for a discipline that covers functional, sensual, linguistic and moral aspects of all the products that surround us.

"I do not love domestic landscapes that are deceptively articulated and unchanging, whether their origin is avant-garde or banal. Their form, defined so arrogantly once and for all, belongs -no paradox- to that of a tomb. I would rather help make some of the bricks with which any individual can gradually and freely change his domestic environment to match his own evolution, whether it's giving tango classes, adopting seven children, or starting up a business to restore antique computers. ${ }^{25}$-Enzo Mari-

Gonzalo Puga Larraín

Designer Catholic University, Chile 1993. Master's in Industrial Design, Domus Academy, Milan. Has worked for Samsung, Seoul and Frogdesign, California, and as a researcher and teacher in Domus Academy. currently works freelance and teaches in the Faculty of Architecture, Design and Urban Studies in the Catholic University. 